\title{
Research Article: Screening of safflower germplasm/advanced material /parental lines against major disease Alternaria leaf spot
}

\section{S.V. PAWAR, S.B. GHUGE, V.M. GHOLVE AND D.S. SUTAR}

Article Chronicle: Received :

15.07.2017;

Accepted :

30.07.2017

KEY WoRds:

Safflower germplasm, Alternari, Leaf spot
SUMMARY : A field experiment with two replications was conducted at the All India Co-ordinated Research Project (AICRP) on oilseeds Safflower at Vasantrao Naik Marathwada Krishi Vidhypeeth (VNMKV) Parbhani, Maharashtra (India) for the screeing of different safflower germplasm/advanced material /parental lines against major disease Alternaria leaf blight.The experiment was conducted with four checks in the year Rabi 2016. Significant differences in resistance to the disease was found in the germplasm/advanced material /parental linestested. Among the 16 lines, 12 lines registered tolerant, 2 lines registered susceptible and 2 lines showed highly susceptible reaction aganist Alternaria leaf spot. This study concludes that screening of safflower germplasm/advanced material /parental lines for resistance/tolerance to the disease Alternaria leaf spot is an prime important step in developing varieties/ hybrids.

How to cite this article : Pawar, S.V., Ghuge, S.B., Gholve, V.M. and Sutar, D.S. (2017). Screening of safflower germplasm/advanced material/parental lines against major disease Alternaria leaf spot. Agric. Update, 12(TECHSEAR-5) : 1208-1212; DOI: 10.15740/HAS/AU/12.TECHSEAR(5)2017/1208-1212.

\section{Author for correspondence :}

\section{S.V. PAWAR}

All India Co-ordinated Research Project on Safflower, Vasantrao Naik Marathwada Krishi Vidyapeeth, PARBHANI (M.S.) INDIA

Email : pawarsv99@ gmail.com

See end of the article for authors' affiliations 